\title{
EFEKTIVITAS JENIS DAN DOSIS FUNGISIDA SERTA PEMANGKASAN DALAM MENEKAN PERTUMBUHAN PENYAKIT KARAT TUMOR
}

\author{
Effectiveness of Types and Doses of Fungicide and Pruning Treatment \\ to Control Gall Rust Disease
}

\author{
Neo Endra Lelana ${ }^{1)}$, Illa Anggraeni ${ }^{1)}$, dan/and Benyamin Dendang ${ }^{2)}$ \\ "Pusat Penelitian dan Pengembangan Peningkatan Produktivitas Hutan \\ Kampus Balitbang Kehutanan, Jl. Gunung Batu No. 5, Bogor 16118 \\ Telp. 0251-8631238, Fax. 0251-7520005 \\ Email: neo 3L@yahoo.com \\ ${ }^{2)}$ Balai Penelitian Teknologi Agroforestry, Ciamis \\ Jl. Raya Ciamis-Banjar Km 4, Ds. Pamalayan Kotak Pos 5 Ciamis \\ Telp. 0265-771352, Fax. 0265-775866
}

Naskah masuk : 29 Agustus 2013; Naskah diterima : 18 September 2014

\begin{abstract}
Efforts to develop control techniques of gall rust disease caused by fungi, Uromycladium tepperianum still need to be continued. This study aims to examine the effectiveness of different types and doses of copper-based and boron-based fungicide formulations in suppressing gall rust disease on sengon. The results showed that both fungicides tested showed different effectiveness. Treatment of CC fungicide at a dose of $10 \%$ with both pruning and non pruning within two months were able to suppress gall rust as many as 4.2 pieces. Meanwhile, treatment of PG fungicide at a dose of $10 \%$ with pruningwere able to suppress gall as many as of 4.8 pieces, treatment without pruning was only able to suppress tumor about 1.6 pieces. CC fungicide apparently could be applied to suppress gall rust without pruning treatment while PG fungicide combined with pruning treatment was more effective.
\end{abstract}

Keywords: Borax, effectiveness, gall rust, sengon, copper

\begin{abstract}
ABSTRAK
Serangan penyakit karat tumor pada sengon (Falcataria moluccana (Miq.) Barneby \& J.W. Grimes) yang disebabkan oleh fungi Uromycladium tepperianum (Sacc.) Mc. Alpin. masih terjadi di hampir semua wilayah pertanaman sengon di Jawa. Upaya pengembangan teknik pengendalian penyakit ini, seperti pengembangan fungisida alternatif masih perlu dilakukan. Tujuan penelitian ialah untuk mengetahui efektivitas jenis dan dosis fungisida hasil formulasi berbasis tembaga dan boron serta pemangkasan yang dilakukan dalam menekan pertumbuhan penyakit karat tumor pada tanaman sengon. Percobaan dilakukan menggunakan rancangan faktorial dalam rancangan acak lengkap dengan tiga faktor, yaitu pemangkasan, jenis fungisida dan dosis yang digunakan. Fungisida sebanyak $10 \mathrm{ml}$ diaplikasikan pada tanaman sengon dengan metode injeksi batang setiap bulan. Hasil penelitian menunjukkan kedua fungisida yang diuji menunjukkan efektivitas yang berbeda. Perlakuan fungisida CC dosis $10 \%$ pada tanaman sengon yang dipangkas dan tidak dipangkas dalam waktu dua bulan mampu menekan karat tumor sebesar 4,2 buah. Pada perlakuan fungisida PG dosis $10 \%$ pada tanaman yang dipangkas mampu menekan karat tumor sebesar 4,8 buah, tetapi pada sengon yang tidak dipangkas mampu menekan karat tumor sebesar 1,6 buah. Fungisida CC lebih efektif menekan karat tumor pada sengon yang tidak dipangkas sedangkan pada sengon yang dipangkas lebih efektif menggunakan fundisida PG.
\end{abstract}

Kata kunci: Boraks, efektivitas, karat tumor, sengon, tembaga

\section{PENDAHULUAN}

Saat ini tanaman sengon (Falcataria moluccana (Miq.) Barneby \& J.W. Grimes) masih menjadi pilihan utama bagi petani untuk dikembangkan di hutan rakyat, terutama di Pulau Jawa. Tanaman ini dapat dikatakan sebagai simbol dari keberhasilan pembangunan hutan rakyat. Pertumbuhannya yang cepat dan pasarnya yang sudah stabil menjadikan tanaman ini makin diminati oleh masyarakat, sehingga luas pertanaman sengon meningkat setiap tahunnya.

Adanya serangan penyakit karat tumor pada tanaman sengon yang disebabkan oleh fungi Uro- 
mycladium tepperianum (Sacc.) Mc. Alpin (Rahayu, 2008; Anggraeni et al., 2010; Widyastuti et al., 2013), sampai saat ini masih menjadi kendala yang cukup serius. Penyakit yang pertama kali terdeteksi di Pulau Seram, Maluku, pada tahun 1996 (Anggraeni \& Santoso, 2003) dan sejak tahun 2003 mulai menyerang pertanaman sengon di Pulau Jawa (Rahayu, 2008), berdasarkan survei terakhir pada akhir 2012 masih terlihat menyerang tanaman sengon dengan intensitas serangan cukup tinggi di beberapa wilayah, seperti Wonosobo, Temanggung, Batang, Ciamis dan Bogor (pengamatan langsung). Menurut Rahayu (2008), terjadinya epidemi penyakit karat tumor pada tanaman sengon dapat mempengaruhi peta pengusahaan tanaman sengon sehingga dapat menjadi ancaman terhadap industri berbasis kayu sengon pada tahun-tahun mendatang.

Berbagai teknik pengendalian penyakit karat tumor dengan menggunakan fungisida komersial maupun beberapa bahan alternatif seperti campuran belerang dan kapur (Anggraeni, 2008; Anggraeni, et al., 2010) dan ter (Rahayu, komunikasi pribadi), telah dikembangkan. Namun demikian pemanfaatan bahan-bahan tersebut masih terkendala dengan efektivitas maupun efisiensi penggunaannya. Selain itu bahan-bahan tersebut yang sebelumnya mudah ditemukan dan harganya dapat terjangkau oleh petani saat ini mulai langka dan relatif mahal. Sebagai contoh ialah penggunaan campuran belerang dan kapur. Bahan tersebut saat ini sudah tidak memungkinkan digunakan karena langkanya bahan belerang yang peredarannya mulai dibatasi oleh pemerintah karena alasan keamanan. Oleh karena itu upaya pengembangan fungisida alternatif masih perlu terus dilakukan.

Tujuan penelitian ialah untuk mengetahui efektivitas jenis dan dosis fungisida hasil formulasi berbasis tembaga dan boron serta pemang- kasan yang dilakukan dalam menekan pertumbuhan penyakit karat tumor pada tanaman sengon.

\section{METODOLOGI}

\section{A. Waktu dan Lokasi Penelitian}

Penelitian dilaksanakan pada bulan Juli sampai dengan bulan Oktober 2012. Penelitian dilakukan di kebun sengon milik rakyat umur 3 tahun di Kecamatan Sukamantri, Kabupaten Ciamis, Jawa Barat.

\section{B. Formula Pestisida dan Bahan Tanaman}

Fungisida yang digunakan dalam penelitian terdiri atas dua jenis formulasi, yaitu fungisida $\mathrm{CC}$ dan PG. Fungisida CC merupakan fungisida dengan formulasi tembaga sulfat $\left(\mathrm{CuSO}_{4}\right)$, asam asetat $\left(\mathrm{CH}_{3} \mathrm{COOH}\right)$ dan natrium dikromat $\left(\mathrm{Na}_{2} \mathrm{Cr}_{2} \mathrm{O}_{7}\right)$ sedangkan fungisida $\mathrm{PG}$ merupakan fungisida dengan formulasi boraks $\left(\mathrm{Na}_{2} \mathrm{H}_{4} \mathrm{BO}_{7}\right)$ dan poliglikol. Pelarut yang digunakan untuk formulasi pestisida yaitu akuades. Tanaman yang digunakan dalam penelitian ini merupakan tanaman sengon yang berumur 3 (tiga) tahun. Tanaman uji dipilih yang rata-rata diameter dan tingginya relatif seragam (Tabel 1).

\section{Metode penelitian}

Penelitian dilakukan menggunakan rancangan faktorial dalam rancangan acak lengkap dengan tiga faktor, yaitu pemangkasan (prunning), jenis fungisida dan dosis yang digunakan. Perlakuan pemangkasan terdiri atas dua taraf, yaitu dengan pemangkasan dan tanpa pemangkasan; perlakuan jenis fungisida terdiri atas dua taraf, yaitu fungisida $\mathrm{CC}$ dan $\mathrm{PG}$; dan perlakuan dosis

Tabel(Table) 1. Rata-rata diameter dan tinggi tanaman uji (The average of diameter and height of tested trees)

\begin{tabular}{ccc}
\hline $\begin{array}{c}\text { Perlakuan } \\
(\text { Treatment })\end{array}$ & $\begin{array}{c}\text { Diameter } \\
\text { (Diameter) }(\mathrm{cm})\end{array}$ & $\begin{array}{c}\text { Tinggi } \\
(\text { Height })(\mathrm{m})\end{array}$ \\
\hline CC $10 \%$ & 11,8 & 7,9 \\
CC 20\% & 11,0 & 7,8 \\
CC 30\% & 11,8 & 8,8 \\
PG 10\% & 11,8 & 8,5 \\
PG 20\% & 12,5 & 8,6 \\
PG 30\% & 12,4 & 8,8 \\
Kontrol & 11,9 & 8,4 \\
\hline
\end{tabular}


terdiri atas empat taraf, yaitu 0 (kontrol), 10, 20, dan 30\%. Masing-masing kombinasi perlakuan menggunakan 5 (lima) ulangan. Aplikasi fungisida dilakukan menggunakan metode injeksi batang. Tanaman dilubangi dengan bor dengan sudut $45^{\circ}$ arah bawah sedalam kurang lebih 5 (lima) $\mathrm{cm}$ untuk optimalisasi pemasukan bahan pestisida. Setiap tanaman dilubangi dua titik dengan arah yang berlawanan pada ketinggian sekitar $30 \mathrm{~cm}$ dan $35 \mathrm{~cm}$ dari tanah. Sebanyak 5 (lima) $\mathrm{ml}$ fungisida diinjeksikan pada masingmasing lubang. Setelah fungisida diinjeksikan kedalam batang, lubang ditutup dengan lilin. Aplikasi fungisida dilakukan setiap bulan sampai bulan kedua. Pada perlakuan pemangkasan, sebelum aplikasi pestisida setiap tanaman uji dibersihkan dari karat tumor dengan cara pemangkasan (pruning) sampai tidak ada karat tumor pada tanaman (jumlah karat tumor 0 ).

\section{Analisis Data}

Penurunan jumlah karat tumor dihitung setiap bulan sampai bulan ke-2 dengan jumlah awal karat tumor merupakan jumlah karat tumor sebelum perlakuan. Data yang diperoleh selanjutnya dianalisis dengan analisis sidik ragam dengan program IBM SPSS Statistics versi 20. Perbedaan antar perlakuan diuji dengan uji lanjut Tukey pada taraf $5 \%(\mathrm{P}<0,05)$. Adanya interaksi dianalisis lebih lanjut dengan program Minitab 15.

\section{HASIL DAN PEMBAHASAN}

\section{A. Hasil}

Fungisida CC dan PG diuji untuk mengetahui efektivitasnya dalam menekan pertumbuhan penyakit karat tumor pada tanaman sengon umur 3 tahun. Berdasarkan hasil analisis sidik ragam, aplikasi fungisida baik CC maupun PG, setelah satu bulan perlakuan belum mampu memberikan pengaruh yang signifikan dalam menekan pertumbuhan karat tumor (Tabel 2). Pada bulan kedua, aplikasi kedua jenis fungisida tersebut sudah mulai memberikan pengaruh dalam menekan pertumbuhan karat tumor (Tabel 3). Sementara itu perlakuan pemangkasan ternyata memberikan pe-

Tabel (Table) 2. Analisis sidik ragam jumlah karat tumor pada taraf $5 \%(\mathrm{P}<0,05)$ (Analysis of variance on the number of gall rust on level of $5 \%(P<0.05))$

\begin{tabular}{lcc}
\hline \multirow{2}{*}{ Sumber keragaman (Source) } & \multicolumn{2}{c}{ Signifikansi (Significance) } \\
\cline { 2 - 3 } & Bulan (Month) ke-1 & Bulan (Month) ke-2 \\
\hline Dosis & 0,813 & $0,000^{*}$ \\
Jenis Fungisida & 0,838 & 0,372 \\
Pemangkasan & $0,000^{*}$ & $0,000^{*}$ \\
Dosis * Jenis Fungisida & 0,476 & 0,321 \\
Dosis * Pemangkasan & 0,535 & 0,454 \\
Jenis Fungisida * Pemangkasan & 0,463 & $0,015^{*}$ \\
Dosis * Jenis Fungisida * Pemangkasan & 0,959 & 0,098 \\
\hline
\end{tabular}

Keterangan (Remarks): * = Perlakuan yang menunjukkan beda nyata pada taraf $5 \%(\mathrm{P}<0,05)$ (Treatments indicating significant difference at the level of $5 \%(P<0.05))$

Tabel(Table) 3. Rata-rata jumlah karat tumor pada tanaman sengon pada perlakuan dengan fungisida CC (The average of total number of gall rust on CC fungicide treatments)

\begin{tabular}{ccccccc}
\hline \multirow{2}{*}{$\begin{array}{c}\text { Dosis } \\
(\text { Dose })\end{array}$} & \multicolumn{3}{c}{ Pemangkasan (Pruning) } & \multicolumn{2}{c}{ Tanpa pemangkasan (Non-pruning) } \\
\cline { 2 - 7 } & $\begin{array}{c}\text { Bulan ke-0 } \\
\text { (Month 0) }\end{array}$ & $\begin{array}{c}\text { Bulan ke-1 } \\
\text { (Month } \text { ) }\end{array}$ & $\begin{array}{c}\text { Bulanke-2 } \\
\text { (Month 2) }\end{array}$ & $\begin{array}{c}\text { Bulanke-0 } \\
\text { (Month 0) }\end{array}$ & $\begin{array}{c}\text { Bulanke-1 } \\
\text { (Month 1) }\end{array}$ & $\begin{array}{c}\text { Bulan ke-2 } \\
\text { (Month 2) }\end{array}$ \\
\hline $10 \%$ & $7,8 \pm 2,9 \mathrm{a}$ & $4,4 \pm 3,2 \mathrm{a}$ & $1,8 \pm 0,8 \mathrm{a}$ & $6,6 \pm 2,3 \mathrm{a}$ & $7,8 \pm 6,0 \mathrm{a}$ & $3,4 \pm 1,1 \mathrm{a}$ \\
$20 \%$ & $9,2 \pm 3,4 \mathrm{a}$ & $4,0 \pm 1,2 \mathrm{a}$ & $2,2 \pm 1,1 \mathrm{a}$ & $12,6 \pm 10,5 \mathrm{a}$ & $12,2 \pm 12,5 \mathrm{a}$ & $2,2 \pm 1,3 \mathrm{a}$ \\
$30 \%$ & $8,8 \pm 5,4 \mathrm{a}$ & $6,4 \pm 2,8 \mathrm{a}$ & $2,0 \pm 1,2 \mathrm{a}$ & $8,4 \pm 4,5 \mathrm{a}$ & $10,4 \pm 4,2 \mathrm{a}$ & $4,4 \pm 2,2 \mathrm{a}$ \\
Kontrol & $8,2 \pm 4,2 \mathrm{a}$ & $5,8 \pm 4,9 \mathrm{a}$ & $6,0 \pm 2,8 \mathrm{~b}$ & $8,8 \pm 5,1 \mathrm{a}$ & $9,6 \pm 6,3 \mathrm{a}$ & $7,2 \pm 1,3 \mathrm{~b}$ \\
\hline
\end{tabular}

Keterangan (Remarks): Angka-angka yang diikuti oleh huruf yang sama pada kolom yang sama tidak menunjukkan beda nyata pada taraf $5 \%(\mathrm{P}<0,05)$ (The numbers followed by the same letter in the same column indicate no significant difference at the level of $5 \%(P<0.05))$ 
Tabel (Table) 4. Rata-rata jumlah karat tumor pada tanaman sengon pada perlakuan dengan fungisida PG (The average of total number of gall rust on PG fungicidet reatments)

\begin{tabular}{ccccccc}
\hline \multirow{2}{*}{$\begin{array}{c}\text { Dosis } \\
(\text { Dose })\end{array}$} & $\begin{array}{c}\text { Bulan ke-0 } \\
\text { (Month 0) }\end{array}$ & $\begin{array}{c}\text { Bulan ke-1 } \\
(\text { Month 1) }\end{array}$ & $\begin{array}{c}\text { Bulan ke-2 } \\
(\text { Month 2) }\end{array}$ & $\begin{array}{c}\text { Bulan ke-0 } \\
(\text { Month 0) }\end{array}$ & $\begin{array}{c}\text { Bulan ke-1 } \\
\text { (Month 1) }\end{array}$ & $\begin{array}{c}\text { Bulan ke-2 } \\
\text { (Month 2) }\end{array}$ \\
\cline { 2 - 7 } $10 \%$ & $10,6 \pm 2,6 \mathrm{a}$ & $5,4 \pm 2,4 \mathrm{a}$ & $1,2 \pm 1,1 \mathrm{a}$ & $12,4 \pm 5,2 \mathrm{a}$ & $12,0 \pm 3,4 \mathrm{a}$ & $5,6 \pm 1,5 \mathrm{a}$ \\
$20 \%$ & $8,8 \pm 3,3 \mathrm{a}$ & $4,6 \pm 2,9 \mathrm{a}$ & $0,6 \pm 0,5 \mathrm{a}$ & $13,2 \pm 9,4 \mathrm{a}$ & $13,8 \pm 8,6 \mathrm{a}$ & $7,6 \pm 7,1 \mathrm{a}$ \\
$30 \%$ & $6,6 \pm 3,9 \mathrm{a}$ & $2,2 \pm 1,6 \mathrm{a}$ & $0,8 \pm 0,8 \mathrm{a}$ & $8,2 \pm 1,9 \mathrm{a}$ & $9,2 \pm 3,6 \mathrm{a}$ & $4,0 \pm 2,1 \mathrm{a}$ \\
Kontrol & $8,2 \pm 4,2 \mathrm{a}$ & $5,8 \pm 4,9 \mathrm{a}$ & $6,0 \pm 2,8 \mathrm{~b}$ & $8,8 \pm 5,1 \mathrm{a}$ & $9,6 \pm 6,5 \mathrm{a}$ & $7,2 \pm 1,3 \mathrm{a}$
\end{tabular}

Keterangan (Remarks): Angka-angka yang diikuti oleh huruf yang sama pada kolom yang sama tidak menunjukkan beda nyata pada taraf $5 \%(\mathrm{P}<0,05)$ (The numbers followed by the same letter in the same column indicate no significant difference at the level of $5 \%(P<0.05))$

ngaruh yang signifikan sejak bulan pertama, sedangkan kedua jenis fungisida terlihat tidak berbeda secara signifikan dalam menekan pertumbuhan karat tumor.

Jumlah karat tumor pada pengamatan bulan pertama dan kedua untuk fungisida $\mathrm{CC}$ disajikan pada Tabel 3, sedangkan fungisida PG disajikan pada Tabel 4. Pada bulan kedua setelah diberi fungisida CC dengan pemangkasan, rata-rata jumlah karat tumor antara dosis 10, 20 dan 30\% tidak berbeda nyata, namun dengan kontrol berbeda nyata. Demikian juga pada perlakuan fungisida CC tanpa pemangkasan, rata-rata jumlah karat tumor antara dosis 10, 20 dan 30\% tidak berbeda nyata, namun dengan kontrol berbeda nyata.
Pada bulan kedua perlakuan fungisida PG dengan pemangkasan, rata-rata jumlah karat tumor antara dosis 10, 20 dan 30\% tidak berbeda nyata namun dengan control berbeda nyata. Sementara itu pada perlakuan fungisida PG tanpa pemangkasan, rata-rata jumlah karat tumor antar dosis dan control tidak berbeda nyata.

Pada pengamatan bulan ke-2 terlihat adanya interaksi yang signifikan antara jenis fungisida dan pemangkasan (Tabel 1). Hal ini menunjukkan bahwa perlakuan pemangkasan dapat diperkuat efektivitasnya dalam menekan pertumbuhan karat tumor dengan penggunaan fungisida tertentu. Tanpa pemangkasan fungisida CC terlihat lebih efektif dalam menekan pertumbuhan karat

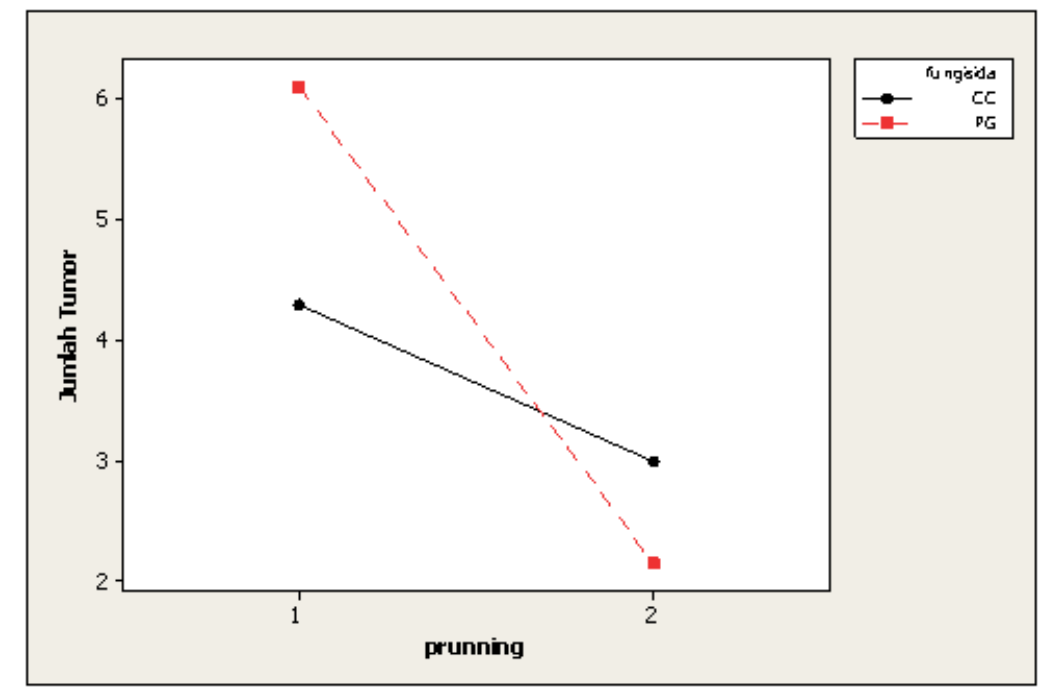

Keterangan (Remarks): Perlakuan (Treatment), 1 = Tanpa pemangkasan (Non pruning), 2 = Dengan pemangkasan (Pruning)

Gambar(Figure) 1. Interaksi antara perlakuan pemangkasan dan jenis fungisida terhadap penurunan jumlah karat tumor pada bulan ke-2 pengamatan (Interaction between pruning and fungicide type to reduce gall rust number in the second month of observation) 
tumor, namun dengan pemangkasan fungisida PG ternyata lebih efektif dalam menekan pertumbuhan karat tumor daripada fungisida CC (Gambar 1).

Berdasarkan jumlah karat tumor pada akhir pengujian terlihat bahwa baik fungisida CC maupun PG dengan dosis $10 \%$ cukup efektif dalam menekan pertumbuhan karat tumor pada tanaman sengon umur 3 tahun. Pemberian fungisida CC dengan pemangkasan rata-rata jumlah karat tumor pada bulan pertama cenderung menurun dan lebih menurun lagi pada bulan kedua. Pada perlakuan fungisida PG dengan sengon yang tidak dipangkas jumlah karat tumor cenderung mengalami kenaikan pada pengamatan bulan pertama, namun akan menurun dengan cepat pada bulan kedua.

\section{B. Pembahasan}

Injeksi batang merupakan metode aplikasi alternatif untuk memasukkan senyawa kimia ke dalam pohon. Metode ini mempunyai keunggulan diantaranya efisiensi penggunaan bahan kimia, mengurangi pencemaran lingkungan, sangat berguna ketika aplikasi tanah dan daun tidak efektif atau terlalu sulit, melindungi organisme non target dan dapat digunakan di daerah dekat pemukiman (Navarro et al., 1992; Al Sammarie \& Akela, 2011). Dengan menggunakan metode injeksi batang, pestisida diharapkan akan ditranslokasikan melalui xylem ke seluruh jaringan tanaman. Kecepatan translokasi berbeda-beda tergantung jenis pestisida, jenis tanaman dan kondisi lingkungan. Pada percobaan ini, aplikasi pestisida CC dan PG dengan dosis 10\% memberikan pengaruh yang signifikan dibandingkan dengan kontrol setelah pengamatan bulan kedua. Hal ini diduga karena deposisi pestisida pada jaringan tanaman meningkat setelah dilakukan injeksi pestisida pada bulan kedua. Pada percobaan injeksi batang menggunakan bahan aktif imidakloprid pada pohon ash, akumulasi tertinggi imidakloprid pada daun terjadi setelah satu bulan injeksi (Sanchez et al., 2009). Keberadaan imidakloprid juga masih terdeteksi setelah satu tahun injeksi.

Efektivitas aplikasi fungisida CC dan PG dalam menekan pertumbuhan karat tumor dapat dikatakan masih lebih rendah dibandingkan dengan penggunaan campuran belerang, kapur dan garam. Pada uji coba sebelumnya yang dilakukan Anggraeni et al. (2010), campuran belerang dan kapur pada bulan pertama rata-rata penghambatan tertinggi dapat mencapai $86,96 \%$ dan pada bulan kedua mencapai 95,88\%, sedangkan pada penelitian ini, rata-rata persentase penghambatan tertinggi mencapai $63,0 \%$ dan pada bulan kedua mencapai $92,4 \%$.

Pengaruh suatu jenis antimikroba terhadap fungi akan berbeda-beda. Suatu antimikroba dapat bersifat fungistatis (antifungi) yaitu merupakan keadaan yang menggambarkan kerja suatu bahan menghambat pertumbuhan fungi, sedangkan fungitoksik (fungisidal) merupakan keadaan yang menggambarkan kerja suatu bahan menghentikan pertumbuhan (membunuh) fungi (Djafaruddin, 2000). Berdasarkan hal tersebut kedua jenis fungisida yang diuji diduga bersifat antifungi terhadap karat tumor karena adanya fluktuasi jumlah karat tumor pada beberapa perlakuan pada bulan pengamatan berikutnya.

Fungisida CC merupakan fungisida yang berbasis tembaga sedangkan fungisida PG merupakan fungisida yang berbasis boron. Menurut Borkow \& Gabbay (2005), tembaga sudah dimanfaatkan sejak lama bahkan ratusan tahun sebelum masehi untuk berbagai macam keperluan sanitasi dan disinfektan. Saat ini, tembaga dalam bentuk ion maupun kompleks secara luas telah digunakan sebagai agen untuk fungisida, bakterisida, nematosida, algasida, moluskisida, purifikasi air dan antifouling. Terobosan terbesar tembaga sebagai fungisida dimulai tahun 1885 dengan ditemukannya "Bourdex mixture" yang merupakan campuran tembaga dengan garam yang efektif mengendalikan penyakit bulai (downy mildew) pada anggur. Penemuan ini selanjutnya berkembang dengan pemanfaatan Bourdex mixture dalam skala yang lebih luas untuk berbagai penyakit pada berbagai tanaman. Mekanisme toksisitas tembaga terhadap fungi terjadi dalam beberapa mekanisme, seperti penurunan integritas membran sel secara cepat sehingga menyebabkan sel kehilangan permeabilitasnya, mampu berikatan dengan deoxy ribonucleic acid (DNA) sehingga dapat menyebabkan terjadinya ikatan silang antara pitapita DNA yang pada akhirnya struktur heliks DNA menjadi tidak beraturan, dan menginaktivasi kerja berbagai macam enzim seperti tirosin fosfatase.

Pada umumnya, informasi mengenai pemanfaatan boron untuk mengendalikan penyakit pada tanaman terbatas. Rolshausen \& Gubler (2005) menunjukkan bahwa penambahan senyawa boron secara signifikan menurunkan kerentanan terhadap penyakit eutypa dieback yang disebabkan oleh Eutypa lata pada anggur. Frenkel et al. (2010) menyatakan bahwa boron yang dicampur 
dengan fungisida komersial dapat meningkatkan penghambatan penyakit hawar daun pada kentang yang disebabkan oleh Phythoptora infestans. Mekanisme toksisitas senyawa boron terhadap fungi diduga karena kemampuannya dalam berinteraksi dengan berbagai molekul penting sehingga mengganggu proses fisiologis di dalam sel. Boron dapat berperan sebagai analog enzim sehingga dapat mengganggu aktivitasnya (Woods, 1994). Studi yang dilakukan Bowen \& Gauch (1966) menunjukkan bahwa boron dapat menghambat kerja enzim aldolase pada Saccharomyces cerevisae sehingga kehilangan kemampuannya untuk memanfaatkan karbohidrat. Selain itu boron dalam bentuk ion dapat menyebababkan oksidasi senyawa penting seperti nicotinamide adenine dinucleotide $\left(\mathrm{NAD}^{+}\right)$, nicotinamide mononucleotide $\left(\mathrm{NMN}^{+}\right)$dan nicotinamide adenine dinucleotide phosphate (NADP ${ }^{+}$)(Lloyd, 1997).

Adanya interaksi yang signifikan antara jenis fungisida dan pemangkasan menunjukkan bahwa kombinasi perlakuan tersebut dapat bersifat sinergis. Namun demikian sinergitas antara kombinasi fungisida dan pemangkasan ditentukan oleh jenis fungisida yang digunakan. Fungisida CC dan PG terlihat lebih bersifat menghambat munculnya tumor baru dibandingkan dengan mematikan tumor yang sudah ada. Dalam percobaan ini sinergitas antara kombinasi perlakuan fungisida PG dan pemangkasan secara signifikan lebih tinggi dibandingkan kombinasi fungisida $\mathrm{CC}$ dan pemangkasan. Dalam hal ini, fungisida PG diduga lebih berperan dalam menghambat proses fisiologis sel fungi karat dibanding fungisida CC, sehingga pertumbuhan tumor baru terhambat.

\section{KESIMPULAN DAN SARAN}

Berdasarkan rata-rata jumlah karat tumor dan persentase penghambatannya, dosis fungisida $\mathrm{CC}$ $10 \%$ efektif menekan pertumbuhan karat tumor mulai bulan kedua pada sengon yang dipangkas dan yang tidak dipangkas, sedangkan dosis fungisida PG 10\% efektif menekan karat tumor pada tanaman yang tidak dipangkas dan lebih efektif lagi jika tanaman sengon dipangkas yang mampu menekan karat tumor sebesar 77\%. Kegiatan pemangkasan secara signifikan dapat membantu menekan pertumbuhan karat tumor.

\section{UCAPAN TERIMA KASIH}

Penulis mengucapkan terima kasih kepada Bapak Barly, peneliti pada Pusat Litbang Keteknikan dan Pengolahan Hasil Hutan, atas bantuannya dalam formulasi fungisida.

\section{DAFTAR PUSTAKA}

Al Samarrie, A.I., \& A.A. Akela. (2011). Distribution of injected pesticides in date palm trees. Agric. Biol.J.N.Am., 2(12): 1416-1426.

Anggraeni, I. (2008). Pengendalian penyakit karat tumor (gall rust) pada sengon (Paraserianthes falcataria) di RPH Pandantoyo, BKPH Pare, KPH Kediri. Workshop Serangan Karat Tumor pada Sengon. Yogyakarta 19 Nopember 2008.

Anggraeni, I., \& Santoso, E. (2003). Penyakit karat puru pada sengon (Paraserianthes falcataria) di Pulau Seram. Buletin Penenlitian Hutan, 636. Pusat Litbang Hutan dan Konservasi Alam Bogor.

Anggraeni, I., Dendang, B., Lelana, N.E. (2010). Pengendalian penyakit karat tumor (Uromycladium tepperianum (Sacc.) Mc. Alpin) pada sengon (Falcataria mollucana (Miq.) Barneby \& J.W. Grimes) di Panjalu Kabupaten Ciamis Jawa Barat. Jurnal Penelitian Hutan Tanaman, 7(5): 273-278.

Borkow, G., \& Gabbay, J. (2005). Copper as a biocidal tool. Curr. Med. Chem., 12:2163-2175.

Bowen, J.E., Gauch, H.G. (1966). Nonessentiality of boron in fungi and the nature of its toxicity. Plant Physiol., 41:319-324.

Djafaruddin. (2000). Dasar-dasar pengendalian penyakit tanaman. Bumi Jakarta: Aksara.

Frenkel, O., Yermiyahu, U., Forbes, G.A., Fry,W.E., \& Shtienberg, D. (2010). Restriction of potato and tomato late blight development by subphytotoxic concentrations of boron. Plant Pathol., 59: 626-633.

Lloyd, J.D. (1997). International status of borate preser-vative systems. In: Proceedings of the Second International Conference on Wood Protection with Diffusible Preservatives and Pesticides. Madison, Wisconsin: Forest Products Society. pp.45-54.

Navarro, C., Fernández-Escobar, R., \& Benlloch,M.. (1992). A low-pressure, trunk-injection method 
for introducing chemical formulations into olive trees. J. Amer. Soc. Hort. Sci., 117(2):357360 .

Rahayu, S. (2008). Penyakit karat tumor pada sengon. Makalah Workshop Serangan Karat Tumor pada Sengon. Yogyakarta 19 Nopember 2008.

Rolshausen, P.E., \& Gubler, W.D. (2005). Use of boron for the control of Eutypa dieback of grapevines. Plant Dis., 89: 734-738.

Sanchez, D.M., Cregg, B.M., McCullough, D.G., Poland, T.M., \& Hollingworth, R.M. (2009).
Distribution of trunk-injected 14C-imidacloprid in ash trees and effects on emerald ash borer (Coleoptera: Buprestidae) adults. Crop Protection, 28: 655661.

Widyastuti, S.M., Harjono, Surya, Z.A. (2013). Initial infection of Falcataria moluccana leaves and Acacia mangium Phyllodes by Uromycladium tepperianum fungi in a laboratory trial. JMHT, 19(3): 187-193.

Woods, W.G. (1994). An introduction to boron: history, sources, uses, and chemistry. Environ. Health Perspect., 102 (Supplement 7): 5-11. 